\title{
Short communication: Cholesterol oxidation products in traditional buttermilk
}

\author{
D. Cais-Sokolińska*1 and M. Rudzińska† \\ *Department of Dairy Technology, and \\ †Department of Food Chemistry and Instrumental Analysis, Faculty of Food Science and Nutrition, Poznań University of Life Sciences, \\ ul. Wojska Polskiego 31, 60-624 Poznań, Poland
}

\begin{abstract}
The aim of this study was to quantitatively and qualitatively assess the content of cholesterol oxidation products in traditional buttermilk after butter production. Cholesterol oxidation products (COP) exhibit a wide spectrum of biological activity, including cytotoxic, carcinogenic, and pro-oxidative properties. Buttermilk has about $2 \mathrm{mg}$ of $\mathrm{COP} / \mathrm{kg}$ of fat, including

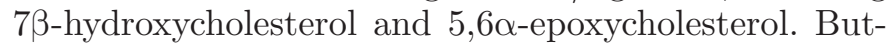
termilk immediately after production had a relatively high level of $7 \beta$-hydroxycholesterol $(1.47 \mathrm{mg} / \mathrm{kg})$, which decreased to $0.61 \mathrm{mg} / \mathrm{kg}$ after storage for $10 \mathrm{~h}$ at $3^{\circ} \mathrm{C}$. During storage, the content of 5,6 $\alpha$-epoxycholesterol increased from 0.50 to $1.40 \mathrm{mg} / \mathrm{kg}$. After $10 \mathrm{~h}$ of storage, the antioxidant potential of the buttermilk decreased (expressed as radical scavenging ability; change in 1,1-diphenyl-2-picrylhydrazyl $=32.2 \%$ ). This study showed the presence of COP in fresh and stored buttermilk and the influence of time on changing the direction of cholesterol oxidation.
\end{abstract}

Key words: buttermilk, cholesterol, oxysterol, DPPH

\section{Short Communication}

Traditional buttermilk (BM) is a natural product resulting from the butter-making process during sweet cream or cream churning. It is intended for direct consumption or as an ingredient of cultured buttermilk. The components of BM depends on its acidity, the composition of the cream, and the conditions of churning. In traditional BM obtained in a butter churn machine, the fat content varies from 0.15 to $0.4 \%$, by the continuous cream method, fat content can reach $0.65 \%$, and from sweet cream up to $0.75 \%$. Buttermilk usually has lower acidity than the plasma of churned cream. It resembles skim milk in its composition and appearance but contains most of the milk fat globule membrane (MFGM; Fu et al., 2014). During the manufacture of

\footnotetext{
Received October 5, 2017.

Accepted January 3, 2018.

${ }^{1}$ Corresponding author: cais@up.poznan.pl
}

butter, materials derived from the MFGM are recovered in the aqueous phase (BM) when milk fat globules are mechanically disrupted upon churning of cream. The MFGM fragments contain polar lipids (glycerophospholipids and sphingolipids), neutral lipids, proteins, glycoproteins, enzymes, and cholesterol (Fauquant et al., 2014). The major sterol present in milk-cholesterol-accounts for at least $95 \%$ of the sterols and is located mainly in the MFGM (Jensen and Newburg, 1995). Cholesterol content in milk ranges from 3.08 to $6.06 \mathrm{~g} / \mathrm{kg}$ of fat (Mesilati-Stahy and Argov-Argaman, 2014 ); on average, it is $3.3 \mathrm{~g} / \mathrm{kg}$ of fat, which equals $135 \mathrm{mg} / \mathrm{kg}$ of milk. In the MFGM, on the other hand, cholesterol content is $1.7 \mathrm{mg} / \mathrm{m}^{2}$ MFGM (Et-Thakafy et al., 2017). For comparison, goat milk contains 1.5 $\mathrm{mg} / \mathrm{m}^{2}$ MFGM and sheep milk $1.8 \mathrm{mg} / \mathrm{m}^{2}$. The content of cholesterol in MFGM is $40 \mathrm{mg} / 100 \mathrm{~g}$ of fat globules, which is $2 \mathrm{~g} / 100 \mathrm{~g}$ of MFGM dry matter or $2 \%$ (Dewettinck et al., 2008). The amount of membrane fat globules is $1.9 \mathrm{~m}^{2} / \mathrm{g}$ of fat. In MFGM, there is 1.7 $\mathrm{mg} / \mathrm{m}^{2}$ of cholesterol (Et-Thakafy et al., 2017). The estimated mass of the MFGM is 2 to $6 \%$ of that of the total fat globules (Lopez, 2011).

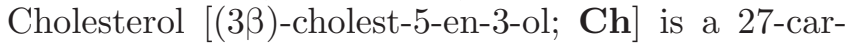
bon animal sterol. Its structure contains a tetracyclic cyclopentanoperhydrophenanthrene, an 8-carbon saturated side chain, and a hydroxyl group in the $3 \beta$ position. Cholesterol levels in dairy products depend on, among other factors, the fat content, heat treatment, milk homogenization, and the type of lactic acid bacteria present. Milk contains approximately $12 \mathrm{mg}$ of cholesterol per $100 \mathrm{~g}$ (Fletouris et al., 1998). According to Kovács et al. (2004), low-fat dairy products have a larger share of the $\mathrm{Ch}$ in fat high-fat products, because the small fatty beads have a relatively large surface area, which accumulates Ch.

Cholesterol, due to the presence of $\Delta^{5}$ unsaturated bond, is subject to numerous chemical reactions, including oxidation. Ex vivo oxidation of Ch occurs primarily through free radicals under the influence of heat, UV, or ionizing radiation in the presence of oxygen. Oxidation of the carbon at the $\mathrm{C}-7$ position is the easiest to accomplish. Through the intermedi- 
ate product, 7-hydroperoxide, isomeric hydroxyl derivatives are formed: $7 \beta$-hydroxycholesterol $(\mathbf{7} \beta-\mathbf{O H C})$ and $7 \alpha$-hydroxycholesterol $(\mathbf{7} \boldsymbol{\alpha}-\mathbf{O H C})$. Another route is the oxidation of $\mathrm{Ch}$ on the carbon atoms forming the double bond (C-5 and C-6), where epoxidation occurs easily. As a result, isomeric epoxides are formed,

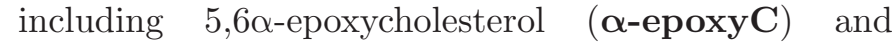
5,63-epoxycholesterol ( $\beta$-epoxyC). Many researchers have reported that cholesterol oxidation products (COP) in foods can reach $1 \%$ of total cholesterol and occasionally $10 \%$ or more (Hur et al., 2007). In addition to cholesterol, the formation of $\mathrm{COP}$ requires reactive oxygen species and is favored by the presence of UFA or transition metals; in some rare cases, the oxidation is enzymatic (Rose-Sallin et al., 1996; Hur et al., 2007). The probability of COP forming in fresh dairy products is very low because the medium is liquid and the oxygen content is low (Sieber, 2005). Milk has a low level of PUFA and of pro-oxidant trace elements such as iron and copper. However, oxidation in fresh dairy products may be dominated by $7 \beta-\mathrm{OHC}$ and $\alpha$-epoxyC (Kumar and Singhal, 1992). The formation of COP in milk and dairy products can only occur under extreme conditions, such as high temperatures for a long period or prolonged storage at high temperatures (Sieber, 2005).

In very low concentrations, oxysterols are natural components of the human body and mediate many physiological functions (Kloudova et al., 2017). They participate in the regulation of $\mathrm{Ch}$ metabolism. However, oxysterol action is also connected with human pathologies (e.g., atherosclerosis, Alzheimer's disease, Parkinson's disease). Cholesterol oxidation products exhibit a wide spectrum of biological activity, such as cellular cytotoxicity, immunosuppressive effects, mutagenicity, carcinogenicity, and pro-oxidative properties (Jusakul et al., 2013; Kulig et al., 2016). The major nonenzymatically formed oxysterols, 7-ketocholesterol (7-ketoC), 7 $\beta$-OHC and $\beta$-epoxyC, have strong cytotoxic properties and are implicated in various pathological states (Lemaire-Ewing et al., 2005; Rimner et al., 2005; Massey, 2006). It has been suggested in the literature that $\mathrm{COP}$ produce different effects depending on whether they are applied separately or in mixtures. For example, a mixture of $7 \beta-\mathrm{OHC}$ and 25 -hydroxycholesterol (25-OHC) had weaker pro-apoptotic effects than 73-OHC alone (Aupeix et al., 1995; Kloudova et al., 2017). Because of the potential health risk of oxysterols, their formation and presence in foods have been the subject of many studies (Seckin and Metin, 2005). Bierzuńska et al. (2017) examined COP found in cheese from buttermilk and showed a correlation between the amount of oxysterols produced in cheese and the antioxidant potential. In the scientific and industrial literature, however, there is no information about the composition and concentration of oxysterols in traditional buttermilk. In addition, observations on traditional BM production technology have prompted us to consider the effect of storage time on the amount and type of COP. The time that elapses between the end of churning and the further use of BM induces changes that may affect the direction of Ch oxidation, the number and type of $\mathrm{COP}$, and the antioxidant potential. In these experiments, attention has been focused on the most common and abundant COP, including cholesterol 25-OHC, cholestanetriol (triolC), $7 \alpha-\mathrm{OHC}, 7 \beta-\mathrm{OHC}, 7-\mathrm{ketoC}$, and $\alpha$ - and $\beta$-epoxyC.

The research material was traditional buttermilk, which was left over after the industrial production of butter from sour cream. The butter production used traditional methods, sometimes on an industrial scale. To cream, comprising $35 \%$ fat $\left[9^{\circ}\right.$ Soxhlet-Henkel (SH) of plasma] after pasteurization $\left(92^{\circ} \mathrm{C}\right.$ for $\left.30 \mathrm{~s}\right)$, the starter culture Lyofast M030N (Sacco, Cadorago, Italy) was added at 10 units of activity per 1,000 $\mathrm{L}$ of cream. The sour cream, comprising $35 \%$ fat, $\mathrm{pH} 5.5\left(13.1^{\circ} \mathrm{SH}\right.$, $21^{\circ} \mathrm{SH}$ of plasma), was churned at $10^{\circ} \mathrm{C}$ for $55 \mathrm{~min}$ to achieve a butter grain size of 2 to $4 \mathrm{~mm}$. The BM was taken to the tank by a gravity drain directly after the churning process and immediately cooled to $3 \pm 0.5^{\circ} \mathrm{C}$ (sample BM-0). Buttermilk was stored in a covered fermentation tank at $3 \pm 0.5^{\circ} \mathrm{C}$ for $10 \mathrm{~h}$ (sample BM10). The tank was manufactured from high-alloy austenitic steel (type 316L-AISI, X2CrNiMo 1713 2-DIN), a stainless chromium-nickel steel, cold-rolled sheet, annealed, with surface roughness (roughness average, Ra) of $0.6 \mu \mathrm{m}$. The current study examined the composition and properties of BM using the methods previously described by Cais-Sokolińska et al. (2016, 2018). The isolation of lactic acid bacteria and determination of the proteolytic and lipolytic activity of the microorganisms was carried out following the method of Bettache et al. (2012).

The main element of the study was to analyze the content of $\mathrm{Ch}$ and COP. Fat from BM was extracted according to the Röse-Gottlieb procedure following ISO method 14156 (ISO, 2001). The Ch content was determined using an AOCS Official Method (AOCS, 2009) by gas chromatography, after a prior sample saponification with $1 \mathrm{~mol} / \mathrm{L} \mathrm{KOH}$ in methanol for $18 \mathrm{~h}$ at room temperature and triple extraction of the unsaponifiables with hexane:tert-butyl methyl ether (MTBE) 1:1 (vol/ vol). The solvent was evaporated under a stream of nitrogen. The dry residues were dissolved in $0.1 \mathrm{~mL}$ of pyridine and silylated with $0.4 \mathrm{~mL}$ of Sylon BTZ (Supelco, Bellefonte, PA). Derivatives of the sterols were separated on an HP 6890 gas chromatograph equipped with a DB-35MS capillary column $(25 \mathrm{~m} \times 0.20 \mathrm{~mm}$; $0.33 \mu \mathrm{m}$; J\&W Scientific, Folsom, CA). A sample was 
injected in splitless mode. The column temperature was held at $100^{\circ} \mathrm{C}$ for $5 \mathrm{~min}$, and then programmed to increase to $250^{\circ} \mathrm{C}$ at $25^{\circ} \mathrm{C} / \mathrm{min}$, held for $1 \mathrm{~min}$, increased to $290^{\circ} \mathrm{C}$ at $3^{\circ} \mathrm{C} / \mathrm{min}$, and finally held for $20 \mathrm{~min}$. The detector temperature was set to $300^{\circ} \mathrm{C}$. Hydrogen was used as a carrier gas at a flow rate of $1.5 \mathrm{~mL} / \mathrm{min}$. $5 \alpha$-Cholestane was used as the internal standard for sterol quantification.

The COP were determined according to the methodology described by Przygoński et al. (2000). Isolated fats were esterified with $10 \%$ sodium methylate in $\operatorname{MTBE}(4: 6, \mathrm{vol} / \mathrm{vol})$, and cholesterol and its oxidation products were extracted with chloroform, followed by fractionation on a Sep-Pak NH2 column (Waters, Milford, MA). Chromatographic analysis of silylated oxysterols was performed on a HP 6890 GC apparatus (Hewlett-Packard, Palo Alto, CA). Separation was carried out on a DB- 5 capillary column $(30 \mathrm{~m} \times 0.25 \mathrm{~mm}$, with a stationary phase film of $0.25 \mu \mathrm{m}$; J\&W Scientific), using a temperature program increasing at $25^{\circ} \mathrm{C} /$ min from $60^{\circ} \mathrm{C}$ to $270^{\circ} \mathrm{C}$, followed by $2.5^{\circ} \mathrm{C} / \mathrm{min}$ until $290^{\circ} \mathrm{C}$ was reached. Helium was applied as a carrier gas at a flow rate of $1 \mathrm{~cm}^{3} / \mathrm{min}$. The injector and detector were held at $300^{\circ} \mathrm{C}$, and a split ratio of 1:40 was used. 19-Hydroxycholesterol was applied as an internal standard. The COP were identified using retention data for standards, previously verified by mass spectrometry utilizing laboratory library and published data.

The ferric reducing antioxidant power (FRAP) was measured; this assay evaluates the ability of analyzed substances to reduce the complex of $\mathrm{Fe}^{3+}-2,4,6$-tris $(2$ pyridyl)-s-triazine (TPTZ) to $\mathrm{Fe}^{2+}$-TPTZ. The ability of an antioxidant to scavenge stable 1,1-diphenyl-2-picrylhydrazyl (DPPH) radicals was evaluated spectrophotometrically, in relation to the radical scavenging ability of the reference substance 6-hydroxy-2,5,7,8tetramethylchroman-2-carboxylic acid (Trolox). Both methods are described by Bierzuńska et al. (2017).

To verify the statistical hypotheses, a level of significance at $\alpha=0.05$ was adopted. The statistical calculations were carried out using Statistica data analysis software (version 10, StatSoft, Tulsa, OK).

We examined the effect of buttermilk storage time on its composition, acidity, water activity, the binding of water, the concentration of lactic acid bacteria, and its proteolytic and lipolytic activity (Table $1 ; P>0.05$ ).

The cholesterol content in BM was 10.86 (BM-0) and $11.04(\mathrm{BM}-10) \mathrm{g} / \mathrm{kg}$ of fat $(P>0.05$, Table 1$)$. Cholesterol content in $1 \mathrm{~kg}$ of buttermilk was $43.44 \mathrm{mg}$, which was much higher than the $2.281 \mathrm{~g} / \mathrm{kg}$ indicated by Fletouris et al. (1998) in butter. Based on literature data, the average content of $\mathrm{Ch}$ in buttermilk is $7.6 \pm$

Table 1. Composition, physicochemical, and microbiological characteristics of buttermilk ${ }^{1,2}$

\begin{tabular}{|c|c|c|}
\hline Item & BM-0 & BM-10 \\
\hline 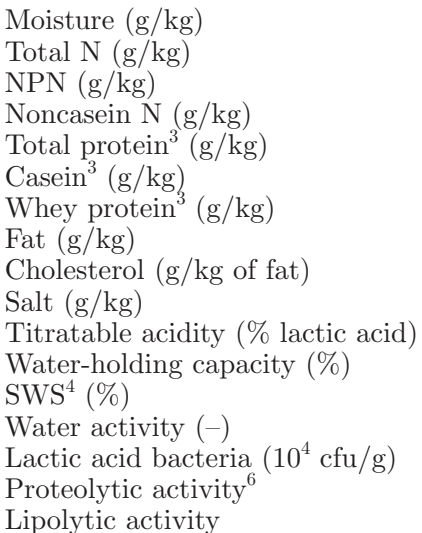 & $\begin{aligned} 914.5 & \pm 1.1^{\mathrm{a}} \\
5.58 & \pm 0.03^{\mathrm{a}} \\
0.37 & \pm 0.07^{\mathrm{a}} \\
1.24 & \pm 0.07^{\mathrm{a}} \\
33.23 & \pm 0.05^{\mathrm{a}} \\
25.32 & \pm 0.01^{\mathrm{a}} \\
5.61 & \pm 0.04^{\mathrm{a}} \\
4.01 & \pm 0.05^{\mathrm{a}} \\
10.86 & \pm 0.10^{\mathrm{a}} \\
7.10 & \pm 0.04^{\mathrm{a}} \\
0.4 & \pm 0.1^{\mathrm{a}} \\
95.6 & \pm 0.2^{\mathrm{a}} \\
& \mathrm{ND}^{5} \\
0.9879 & \pm 0.0007^{\mathrm{a}} \\
2.14 & \pm 0.2^{\mathrm{a}} \\
& -\end{aligned}$ & $\begin{aligned} 913.6 & \pm 1.6^{\mathrm{a}} \\
5.53 & \pm 0.04^{\mathrm{a}} \\
0.38 & \pm 0.05^{\mathrm{a}} \\
1.24 & \pm 0.04^{\mathrm{a}} \\
33.23 & \pm 0.03^{\mathrm{a}} \\
25.31 & \pm 0.04^{\mathrm{a}} \\
5.60 & \pm 0.02^{\mathrm{a}} \\
4.00 & \pm 0.02^{\mathrm{a}} \\
11.04 & \pm 0.35^{\mathrm{a}} \\
7.10 & \pm 0.02^{\mathrm{a}} \\
0.4 & \pm 0.2^{\mathrm{a}} \\
95.4 & \pm 0.4^{\mathrm{a}} \\
& \mathrm{ND} \\
0.9891 & \pm 0.0010^{\mathrm{a}} \\
2.51 & \pm 0.6^{\mathrm{a}} \\
& -\end{aligned}$ \\
\hline \multicolumn{3}{|c|}{$\begin{array}{l}{ }^{a} \text { Values within a row with different lowercase superscripts indicate statistically significant differences at } \alpha= \\
0.05 \text {. } \\
{ }^{1} \text { BM- } 0=\text { control sample buttermilk; BM- } 10=\text { buttermilk after } 10 \mathrm{~h} \text { of storage. } \\
{ }^{2} \text { Values represent mean } \pm \mathrm{SD}(\mathrm{n}=7) \text {. } \\
{ }^{3} \text { Total protein }=(\text { total } \mathrm{N}-\mathrm{NPN}) \times 6.38 \text {; casein }=(\text { total } \mathrm{N}-\text { noncasein } \mathrm{N}-\mathrm{NPN}) \times 6.38 \text {; whey protein }= \\
(\text { noncasein } \mathrm{N}-\mathrm{NPN}) \times 6.38 \text {. } \\
{ }^{5} \text { Spontaneous whey syneresis. } \\
{ }^{6} \text { Pot detected. } \\
\text { Proteolytic activity using plate count agar with } 1 \% \text { and } 2 \%(\mathrm{wt} / \mathrm{vol}) \text { skim milk; a slight reaction was detected } \\
\text { with } 1 \% \text { skim milk and no activity was observed with } 2 \% \text {. }\end{array}$} \\
\hline
\end{tabular}


$3.4 \mathrm{~g} / \mathrm{kg}$ of fat (Bourlieu et al., 2018). The Ch content in cheese from BM was $12.32 \mathrm{~g} / \mathrm{kg}$ of fat (Bierzuńska et al., 2017). The higher content of Ch in BM than in butter is due to the presence of mainly small fat globules in BM. They have a relatively large surface area that allows Ch to accumulate between the MFGM and triacylglycerol (Martin, 1989). Bonczar et al. (2016) showed no effect of storage time (2 wk) on the Ch content in yogurt, kefir, and cultured milk.

Two oxosteroids were identified in the tested $\mathrm{BM}$ samples: $7 \beta-\mathrm{OHC}$ and $\alpha$-epoxyC (Table 2). The amount of the former compound was 2.4 times more in BM-0 than in BM-10, decreasing significantly to $0.61 \mathrm{mg} /$ $\mathrm{kg}$ of fat $(\mathrm{y}=-0.09 \mathrm{x}+1.47 ; P<0.05)$ after $10 \mathrm{~h}$. The reverse was shown for $\alpha$-epoxyC content. During storage, the amount of $\alpha$-epoxyC increased from 0.50 $\mathrm{mg} / \mathrm{kg}$ of fat in BM-0 to $1.40 \mathrm{mg} / \mathrm{kg}$ of fat in BM-10 (y $=0.09 \mathrm{x}+0.5 ; P<0.05)$. In both samples, the sum of COP was about $2 \mathrm{mg} / \mathrm{kg}$, which accounted for $0.02 \%$ of the cholesterol content. Cholesterol can be oxidized by free radical reactions or by enzymatic reactions. 7-Hydroxy derivatives of cholesterol are not stable and can react with oxygen formed by other products. Their content changes during storage and it depends on many factors, including temperature, access of light, enzymes, and water content in product. The probability of COP presence in fresh dairy products is very low. Because of the high content of PUFA, BM is susceptible to oxidative deterioration. In the case of the studied BM, the occurrence of COP was caused by exposure to oxygen and water as well as the decreased $\mathrm{pH}$ level. A number of research data indicate that fresh cream and butter do not contain COP (Pie et al., 1990; Sieber, 2005). Bierzuńska et al. (2017) noted a total COP concentration of $1.17 \mathrm{mg} / \mathrm{kg}$ of fat in fresh white cheese made from buttermilk. Only technological activities, such as heating, can cause their presence or increase their amount. In fresh white cheese made from buttermilk, $7 \beta-\mathrm{OHC}$, $\beta$-epoxyC, and 25-OHC dominated (Bierzuńska et al., 2017). However, during refrigerated storage after $30 \mathrm{~d}$, total COP concentration reached $4.88 \mathrm{mg} / \mathrm{kg}$. Such a large increase in COP was halted by the introduction of whey protein concentrate. After $30 \mathrm{~d}$ of storage with whey protein concentrate, only $7 \beta-\mathrm{OHC}$ and $\beta$-epoxyC were found in the cheese from buttermilk, in a total amount of $1.02 \mathrm{mg} / \mathrm{kg}$ of fat (Bierzuńska et al., 2017). The content of oxysterols in foods is highly variable and depends on processing. For example, total COP contents in raw and boiled shrimp are 38.9 and 43.6 $\mathrm{mg} / \mathrm{kg}$ of fat, respectively (Hernández Becerra et al., 2014). Often total COP are expressed not per kilogram of fat, but per kilogram of sample. Iberian pork contains COP at $1.7 \mathrm{mg} / \mathrm{kg}$ of muscle (raw), $3.3 \mathrm{mg} / \mathrm{kg}$
Table 2. Levels $\left(\mathrm{mg} / \mathrm{kg}\right.$ of fat) of oxysterols in buttermilk ${ }^{1,2}$

\begin{tabular}{lcc}
\hline Oxysterol $^{3}$ & BM-0 & BM-10 \\
\hline $7 \alpha-$ OHC & $\mathrm{ND}^{4}$ & $\mathrm{ND}$ \\
$7 \beta$-OHC & $1.47 \pm 0.05^{\mathrm{b}}$ & $0.61 \pm 0.06^{\mathrm{a}}$ \\
$\beta$-EpoxyC & $\mathrm{ND}$ & $\mathrm{ND}$ \\
$\alpha$-EpoxyC & $0.50 \pm 0.06^{\mathrm{a}}$ & $1.40 \pm 0.07^{\mathrm{b}}$ \\
TriolC & $\mathrm{ND}$ & $\mathrm{ND}$ \\
$25-\mathrm{OHC}$ & $\mathrm{ND}$ & $\mathrm{ND}$ \\
7 -KetoC & $\mathrm{ND}$ & $\mathrm{ND}$ \\
$\Sigma$ COP & $1.97 \pm 0.07^{\mathrm{a}}$ & $2.01 \pm 0.10^{\mathrm{a}}$ \\
\hline
\end{tabular}

a,b Values within a row with different lowercase superscripts indicate statistically significant differences at $\alpha=0.05$.

${ }^{1} \mathrm{BM}-0=$ control sample buttermilk; BM-10 = buttermilk after $10 \mathrm{~h}$ of storage.

${ }^{2}$ Values represent mean $\pm \mathrm{SD}(\mathrm{n}=7)$.

${ }^{3} 7 \alpha$-OHC $=7 \alpha$-hydroxycholesterol; $7 \beta-\mathrm{OHC}=7 \beta$-hydroxycholesterol; $\beta$-epoxyC $=5,6 \beta$-epoxycholesterol; $\alpha$-epoxyC $=5,6 \alpha$-epoxycholesterol; triolC $=$ cholestanetriol; $25-\mathrm{OHC}=25$-hydroxycholesterol; 7 -ketoC $=$ 7-ketocholesterol; $\Sigma \mathrm{COP}=$ sum of cholesterol oxidation products.

${ }^{4}$ Not detected.

of muscle (fried), $3.4 \mathrm{mg} / \mathrm{kg}$ of muscle (grilled), and $3.6 \mathrm{mg} / \mathrm{kg}$ of muscle (roasted; Broncano et al., 2009). Mixed vegetables in canned baby foods contain total COP of $0.8 \mathrm{mg} / \mathrm{kg}$, protein athletic supplement powder contains $8.6 \mathrm{mg} / \mathrm{kg}$, and vanilla yogurt contains 1.3 $\mathrm{mg} / \mathrm{kg}$ (Sander et al., 1989).

The 10-h storage time for BM did not alter FRAP $(\Delta$ FRAP potential $=0.002 \mathrm{mmol} / \mathrm{L} ; P>0.05$, Table $3)$. In contrast, the DPPH radical scavenging ability $(\triangle \mathrm{DPPH}=32.2 \%, P<0.05$, Table 3$)$ was decreased. The DPPH value in BM00 was $0.152 \mathrm{mmol} / \mathrm{kg}$, which is comparable to the antiradical power (against the DPPH radical) noted by Najgebauer-Lejko and Sady (2015) in BM that consisted of defatted milk powder and milk proteins $[0.131 \mathrm{mmol}$ of Trolox equivalents $(\mathbf{T E}) / \mathrm{kg}]$. The same BM had FRAP $=0.235 \mathrm{mmol}$ of $\mathrm{Fe}^{2+} / \mathrm{L}$. On the other hand, in a sample of defatted milk powder and natural buttermilk, the antiradical power amounted to $0.140 \mathrm{mmol}$ of TE $/ \mathrm{kg}$. Flavored BM with strawberry and rhubarb exhibited $0.88 \mathrm{mmol}$ of TE $/ \mathrm{kg}$ and FRAP $=1.64 \mathrm{mmol}$ of $\mathrm{Fe}^{2+} / \mathrm{L}$ (Najgebauer-Lejko and Sady, 2015). Antioxidant properties are caused by antioxidant compounds present in fermented milk: casein, whey proteins, peptides and amino acids, coenzyme Q10, enzymatic systems (superoxide dismutase, catalase, glutathione peroxidase), as well as the antioxidant activity of lactic acid bacteria (NajgebauerLejko et al., 2011). The efficiency of the lipophilic antioxidants in BM is the result of a greater variety, high thermal stability and, especially, the synergistic interaction between individual lipophilic and hydrophilic antioxidants. They play an important role in the processing of $\mathrm{BM}$, protecting against the formation of undesirable compounds. 
Table 3. Antioxidant activity characteristics of buttermilk ${ }^{1,2}$

\begin{tabular}{lcc}
\hline Characteristic $^{3}$ & BM-0 & BM-10 \\
\hline FRAP (mmol/L) & $0.242 \pm 0.015^{\mathrm{a}}$ & $0.240 \pm 0.010^{\mathrm{a}}$ \\
DPPH (mmol/kg) & $0.152 \pm 0.056^{\mathrm{b}}$ & $0.103 \pm 0.021^{\mathrm{a}}$ \\
\hline
\end{tabular}

$\overline{\mathrm{a}, \mathrm{b}}$ Values within a row with different lowercase superscripts indicate statistically significant differences at $\alpha=0.05$.

${ }^{1} \mathrm{BM}-0=$ control sample buttermilk; BM-10 = buttermilk after $10 \mathrm{~h}$ of storage.

${ }^{2}$ Values represent mean $\pm \mathrm{SD}(\mathrm{n}=7)$.

${ }^{3} \mathrm{FRAP}=$ ferric reducing antioxidant power in mmol of $\mathrm{Fe}^{2+} ; \mathrm{DPPH}$ $=$ antiradical power (1,1-diphenyl-2-picrylhydrazyl) in mmol of Trolox equivalents.

Only 2 COP were identified directly after butter production: $7 \beta-\mathrm{OHC}$ and $\alpha$-epoxyC. The toxicity of individual COP is not the same. Triol, which is formed during oxidation of epoxy-derivatives, is the most toxic oxysterol. When the content of epoxides decreases, that of triol increases, so it is important to know how and when this process occurs. Model studies on the formation of volatile compounds generated by a thermal treatment of stigmasterol were performed and hypothetical pathways leading to formation of 2 compounds were presented (Derewiaka et al., 2017). Identification of volatiles formed during cholesterol oxidation permits the use of a rapid and sensitive method for determination of the content of $\mathrm{COP}$ in food products. If determination of 1 or 2 volatile compounds indicates that COP are formed, it could be a good tool for producing safer food products because individual COP have different biological activities and different roles in the pathogenesis of diseases.

Total COP quantity amounted to $1.97 \mathrm{~g} / \mathrm{kg}$. Although the sum of $\mathrm{COP}$ after $10 \mathrm{~h}$ of storage did not change, the proportion of oxidation products did change. The content of $7 \beta-\mathrm{OHC}$ decreased by $59 \%$, and that of $\alpha$-epoxyC increased almost 3-fold. Other COP were not identified after storage. During storage of BM, its antiradical power decreased by $32 \%$ (expressed as mmol of TE). If the total content of COP in BM does not change during storage but DPPH decreases significantly, this implies that other factors, such as lipid oxidation, were more significant than cholesterol oxidation. Fatty acids are more easily oxidized than cholesterol (Ch is more stable). The current study has shown that even a short storage time $(10 \mathrm{~h})$ affects the synthesis of COP and the antioxidant potential of BM. Most likely, factors such as exposure to oxygen and light during and after storage were involved. The results of this preliminary study point to new attributes that may be used to increase the commercial value and health-beneficial properties of buttermilk.

\section{ACKNOWLEDGMENTS}

A part of the study was supported by grant no. 508.784.00/UPP-KTM from the Polish Ministry of Science and Higher Education.

\section{REFERENCES}

AOCS. 2009. Official Method AOCS 6-91. Determination of the composition of the sterol fraction of animal and vegetable oils and fats by TLC and capillary GLC; First Action 2009. In Official Methods and Recommended Practices of the AOCS. 6th ed. D. Firestone, ed. The American Oil Chemists' Society, Urbana, IL.

Aupeix, K., D. Weltin, J. E. Meija, M. Christ, J. Marchal, J. M. Freyssinet, and P. Bischoff. 1995. Oxysterol-induced apoptosis in human monocytic cell lines. Immunobiology 194:415-428.

Bettache, G., A. Fatma, H. Miloud, and K. Mebrouk. 2012. Isolation and identification of lactic acid bacteria from dhan, a traditional butter and their major technological traits. World Appl. Sci. J. $17: 480-488$.

Bierzuńska, P., D. Cais-Sokolińska, M. Rudzińska, and A. GramzaMichałowska. 2017. Evaluation of antioxidant activity of whey protein to improve cholesterol oxidation stability in fresh white cheese from buttermilk. J. Food Nutr. Res. 56:101-108.

Bonczar, G., M. B. Walczycka, J. Domagała, K. Maciejowski, D. Najgebauer-Lejko, M. Sady, and M. Wszołek. 2016. Effect of dairy animal species and of the type of starter cultures on the cholesterol content of manufactured fermented milks. Small Rumin. Res. 136:22-26.

Bourlieu, C., D. Cheillan, M. Blot, P. Daira, M. Trauchessec, S. Ruet, J. Y. Gassi, E. Beaucher, B. Robert, N. Leconte, S. Bouhallab, F. Gaucheron, G. Gésan-Guiziou, and M. C. Michalski. 2018. Polar lipid composition of bioactive dairy co-products buttermilk and butterserum: Emphasis on sphingolipid and ceramide isoforms. Food Chem. 240:67-74.

Broncano, J. M., M. J. Petrón, V. Parra, and M. L. Timón. 2009. Effect of different cooking methods on lipid oxidation and formation of free cholesterol oxidation products (COPs) in Latissimus dorsi muscle of Iberian pigs. Meat Sci. 83:431-437.

Cais-Sokolińska, D., B. Stachowiak, Ł. K. Kaczyński, P. Bierzuńska, and B. Górna. 2018. The stability of the casein-gluconate matrix in reduced-lactose kefir with soluble fraction polysaccharides containing $\beta$-glucan from Pleurotus ostreatus. Int. J. Dairy Technol. 71:122-130. https://doi.org/10.1111/1471-0307.12429.

Cais-Sokolińska, D., J. Wójtowski, and J. Pikul. 2016. Lactose hydrolysis and lactase activity in fermented mixtures containing mare's, cow's, sheep's and goat's milk. Int. J. Food Sci. Technol. 51:2140-2148.

Derewiaka, D., D. Zaręba, M. Obiedziński, and A. Matuszewska-Janica. 2017. Volatile markers of cholesterol thermal changes. Eur. J. Lipid Sci. Technol. 119:1600486.

Dewettinck, K., R. Rombaut, N. Thienpont, T. T. Le, K. Messens, and J. Van Camp. 2008. Nutritional and technological aspects of milk fat globule membrane material. Int. Dairy J. 18:436-457.

Et-Thakafy, O., F. Guyomarch, and L. Christelle. 2017. Lipid domains in the milk fat globule membrane: Dynamics investigated in situ in milk in relation to temperature and time. Food Chem. 220:352-361.

Fauquant, J., E. Beaucher, C. Sinet, B. Robert, and C. Lopez. 2014 Combination of homogenization and cross-flow microfiltration to remove microorganisms from industrial buttermilks with an efficient permeation of proteins and lipids. Innov. Food Sci. Emerg. Technol. 21:131-141.

Fletouris, D. J., N. A. Botsoglou, I. E. Psomas, and A. I. Mantis. 1998. Rapid determination of cholesterol in milk and milk products by direct saponification and capillary gas chromatography. J. Dairy Sci. 81:2833-2840. 
Fu, S., Z. Shen, S. Ajlouni, K. Ng, L. Sanguansri, and M. A. Augustin. 2014. Interactions of buttermilk with curcuminoids. Food Chem. 149:47-53.

Hernández Becerra, J. A., A. A. Ochoa Flores, G. Valerio-Alfaro, I Soto-Rodriguez, M. T. Rodríguez-Estrada, and H. S. García. 2014. Cholesterol oxidation and astaxanthin degradation in shrimp during sun drying and storage. Food Chem. 145:832-839.

Hur, S. J., G. B. Park, and S. T. Joo. 2007. Formation of cholesterol oxidation products (COPs) in animal products. Food Control 18:939-947.

ISO. 2001. ISO 14156: Milk and milk products-Extraction methods for lipids and liposoluble compounds. International Organization for Standardization (ISO), Geneva, Switzerland.

Jensen, R., and D. Newburg. 1995. Bovine milk lipids. Pages 260-267 in Handbook of Milk Composition. Acad. Press, New York, NY.

Jusakul, A., W. Loilome, N. Namwat, A. Techasen, R. Kuver, G. Ioannou, C. Savard, W. G. Haigh, and P. Yongvanit. 2013. Antiapoptotic phenotypes of cholestan- $3 \beta, 5 \alpha, 6 \beta$-triol-resistant human cholangiocytes: Characteristics contributing to the genesis of cholangiocarcinoma. J. Steroid Biochem. Mol. Biol. 138:368-375.

Kloudova, A., F. P. Guengerich, and P. Soucek. 2017. The role of oxysterols in human cancer. Trends Endocrinol. Metab. 28:485-496.

Kovács, A., R. Dulicsek, L. Varga, J. Szigeti, and Z. Herpai. 2004. Relationship between cholesterol and fat contents of commercial dairy products. Acta Aliment. 33:387-395.

Kulig, W., Ł. Ćwiklik, P. Jurkiewicz, T. Róg, and I. Vattulainen. 2016. Cholesterol oxidation products and their biological importance. Chem. Phys. Lipids 199:144-160.

Kumar, N., and O. P. Singhal. 1992. Effect of processing conditions on the oxidation of cholesterol in ghee. J. Sci. Food Agric. 58:267-273.

Lemaire-Ewing, S., C. Prunet, T. Montange, A. Vejux, A. Berthier, G. Bessède, L. Corcos, P. Gambert, D. Néel, and G. Lizard. 2005. Comparison of the cytotoxic, pro-oxidant and pro-inflammatory characteristics of different oxysterols. Cell Biol. Toxicol. 21:97-114.

Lopez, C. 2011. Milk fat globules enveloped by their biological membrane: Unique colloidal assemblies with a specific composition and structure. Curr. Opin. Colloid Interface Sci. 16:391-404.
Martin, R. W. 1989. Electron microscopic localization of cholesterol in bovine milk fat globules. Food Microstruct. 8:3-9.

Massey, J. B. 2006. Membrane and protein interactions of oxysterols. Curr. Opin. Lipidol. 17:296-301.

Mesilati-Stahy, R., and N. Argov-Argaman. 2014. The relationship between size and lipid composition of the bovine milk fat globule is modulated by lactation stage. Food Chem. 145:562-570.

Najgebauer-Lejko, D., and M. Sady. 2015. Estimation of the antioxidant activity of the commercially available fermented milks. Acta Sci. Pol. Technol. Aliment. 14:387-396.

Najgebauer-Lejko, D., M. Sady, T. Grega, and M. Walczycka. 2011. The impact of tea supplementation on microflora, $\mathrm{pH}$ and antioxidant capacity of yoghurt. Int. Dairy J. 21:568-574.

Pie, J. E., K. Spahis, and C. Seillan. 1990. Evaluation of oxidative degradation of cholesterol in food and food ingredients: identification and quantification of cholesterol oxides. J. Agric. Food Chem. 38:973-979.

Przygoński, K., H. Jeleń, and E. Wąsowicz. 2000. Determination of cholesterol oxidation products in milk powder and infant formulas by gas chromatography and mass spectrometry. Nahrung 44:122125.

Rimner, A., S. A. Makdessi, H. Sweidan, J. Wischhusen, B. Rabenstein, K. Shatat, P. Mayer, and I. Spyridopoulos. 2005. Relevance and mechanism of oxysterol stereospecifity in coronary artery disease. Free Radic. Biol. Med. 38:535-544.

Rose-Sallin, C., R. Sieber, J. O. Bosset, and R. Tabacchi. 1996. Mecanismes d'oxydation du cholesterol: Un article de synthese. OCL 3:227-235

Sander, B. D., P. B. Addis, S. W. Park, and D. E. Smith. 1989. Quantification of cholesterol oxidation products in a variety of foods. J. Food Prot. 52:109-114.

Seckin, A. K., and M. Metin. 2005. The effect of process temperature and time on the occurrence of the products of cholesterol oxidation in butter. Int. J. Food Sci. 40:903-906.

Sieber, R. 2005. Oxidised cholesterol in milk and dairy products. Int. Dairy J. 15:191-206. 